\title{
Cannibalism, growth performance, and body composition of giant trahira juveniles under different photoperiods
}

\author{
Shayenne Elizianne Ramos( ${ }^{(1)}$, Aline Ferreira Souza de Carvalho ${ }^{(1)}$, Tássia Flávia Dias Castro(1), \\ Ana Carina Nogueira Vasconcelos ${ }^{(2)}$, Galileu Crovatto Veras ${ }^{(3)}$, \\ Carlos Alberto Mourão Júnior ${ }^{(4)}$ and Luis David Solis Murgas ${ }^{(1)}$
}

\begin{abstract}
(1)Universidade Federal de Lavras, Departamento de Medicina Veterinária, Setor de Fisiologia e Farmacologia, Caixa Postal 3.037, CEP 37200-000 Lavras, MG, Brazil. E-mail: shayenneramos@yahoo.com.br, alineferreirascarvalho@gmail.com, tassia_fd@hotmail.com, Ismurgas@dmv.ufla.br(2)Universidade Federal do Rio Grande do Sul, Departamento de Ciência Animal, Setor de Aquacultura, CEP 91540-000 Porto Alegre, RS, Brazil. E-mail: aninha-nv@hotmail.com ${ }^{(3)}$ Universidade Federal do Pará, Instituto de Estudos Costais, CEP 68600-000 Bragança, PA, Brazil. E-mail: galileu@ufpa.br ${ }^{(4)}$ Universidade Federal de Juiz de Fora, Departamento de Fisiologia, Laboratório de Neurofisiologia e Endocrinologia, CEP 36036-900 Juiz de Fora, MG, Brazil. E-mail: carlos.mourao@ufjf.edu.br
\end{abstract}

\begin{abstract}
The objective of this work was to determine the effect of photoperiod on the cannibalism, growth, and body composition of giant trahira (Hoplias intermedius) juveniles. A completely randomized design was employed, with four photoperiods - 0L:24D, 6L:18D, 12L:12D, and 18L:6D, hours of light (L): dark (D) - and four replicates, for a period of 90 days. The analyzed parameters were: cannibalism, growth in weight and length, food consumption, feed conversion, protein efficiency rate, muscle growth, and body composition (moisture, lipid, ash, and crude protein). Fish from the 12L:12D photoperiod showed the highest survival rate and no cannibalism, as well as a great uniformity for length and mass values at the end of the experiment. The best photoperiod for giant trahira juveniles is $12 \mathrm{~L}: 12 \mathrm{D}$, as these fish showed growth uniformity and no cannibalism, while fish from the 6L:18D and 18L:6D groups had a greater diameter of white muscle fibers and a higher frequency of greater diameter fibers. Giant trahira showed the lowest value for lipids at 6L:18D and the highest value at 12L:12D. Photoperiod affects survival and cannibalism; regarding body composition, only lipids are influenced by photoperiod.
\end{abstract}

Index terms: Hoplias intermedius, fish, lipids, muscle.

\section{Canibalismo, desempenho de crescimento e composição corporal de juvenis de trairão em diferentes fotoperíodos}

Resumo - O objetivo deste trabalho foi determinar o efeito do fotoperíodo sobre o canibalismo, o crescimento e a composição corporal de juvenis de trairão (Hoplias intermedius). Um delineamento inteiramente casualizado foi empregado, com quatro fotoperíodos - 0L:24D, 6L:18D, 12L:12D e 18L:6D horas de luz (L) por horas de escuridão (D) - e quatro repetições, pelo período de 90 dias. Os parâmetros analisados foram: canibalismo, crescimento em peso e comprimento, consumo alimentar, conversão alimentar, taxa de eficiência proteica, crescimento muscular e composição corporal (umidade, lipídios, cinzas e proteína bruta). Os peixes do fotoperíodo 12L:12D apresentaram maior taxa de sobrevivência e nenhum canibalismo, bem como grande uniformidade nos valores de comprimento e massa ao final do experimento. $\mathrm{O}$ melhor fotoperíodo para juvenis de trairão é 12L:12D, uma vez que os peixes mostraram uniformidade de crescimento e nenhum canibalismo, enquanto peixes dos grupos 6L:18D e 18L:6D apresentaram maior diâmetro de fibras musculares brancas e maior frequência de fibras de maior diâmetro. Os peixes apresentaram menor valor de lipídios no fotoperíodo 6L:18D, e o maior valor no 12L:12D. O fotoperíodo afeta a sobrevivência e o canibalismo; quanto à composição corporal, somente os lípidos são influenciados pelo fotoperíodo.

Termos para indexação: Hoplias intermedius, peixes, lipídio, músculo.

\section{Introduction}

The giant trahira Hoplias intermedius (Günther, 1864) has aroused the interest of researchers and farmers as a potential fish for aquaculture purposes.
This fish adapts well to captive conditions, has quality meat, high rate of mass gain, and shows features for sport fishing. However, this species has carnivorous habits, which may result in low survival rate, making it difficult to cultivate it (Luz et al., 2000).
Pesq. agropec. bras., Brasília, v.53, n.6, p.664-672, June 2018 DOI: 10.1590/S0100-204X2018000600002 (c) BY This is an open-access article distributed under the Creative Commons Attribution 4.0 International License 
Several factors have been linked to cannibalism. Population factors, as size and density, have been correlated with the incidence of cannibalistic behavior (Naumowicz et al., 2017). Besides, environmental factors such as feed, diet supplementation, refuges, color, and shape of tanks, light intensity, photoperiod, and temperature can also increase cannibalism (Naumowicz et al., 2017). However, the size uniformity of $H$. intermedius has been considered important to minimize cannibalism (Luz et al., 2000).

The relationship between cannibalism and photoperiod has been shown in some species. In Steindachneridion scriptum larvae, the absence of light (0L:24D photoperiod) provided better effect on growth, but high mortality and cannibalism were observed. Dark conditions provided the chance of cannibalism and agonistic interactions (Schütz et al., 2008). Nevertheless, in Pseudoplatystoma corruscans larvae, the cannibalism was lower with decreasing photoperiod (Campagnolo \& Nuñer, 2008), showing that there are different responses to photoperiod for each species of fish.

Changes in animal growth can be caused by photoperiod, as it acts on the somatotrophic axis, mass gain, and food intake, in some fish species (Taylor \& Migaud, 2009; Biswas et al., 2010; Falcón et al., 2010). Biswas et al. $(2008,2010)$ showed that the growth of Pagrus major, subjected to long photoperiods, was stimulated with a significant increase of food intake.

The postembryonic growth of muscle involves myogenic progenitor cells through the process of hypertrophy and hyperplasia (Johnston, 2006). Hypertrophy is characterized by the increase in length and diameter of the existing muscle fibers, while hyperplasia is the formation of new fibers (Johnston et al., 2009). In adults and juveniles, abiotic factors such as photoperiods affect the signaling pathways that regulates the proliferation and differentiation of myogenic progenitor cells. The photoperiod can control the myoblast proliferation, which results in proportional increases of the myotube production and the myonuclear content of fibers (Johnston, 2006). Therefore, the photic environment parameter can determine myogenesis rate, and can also change the distribution of muscle fibers in both number and size.

Additionally, the photoperiod can cause changes in the body composition of fish, as it influences the stimulation of the metabolic activities, feeding strategy and the efficiency of the nutrient use of some fish (Reynalte-Tataje et al., 2002; Veras et al., 2014). Veras et al. (2014) found that the 18L:6D photoperiod contributes to the concentration increase of crude protein, and less fat deposition in the fillet of Oreochromis niloticus, since it influences the metabolic rates for the mobilization of nutrients, particularly of protein deposition and utilization of body fat.

All this information shows how much the photoperiod can interfere in the behavior, development, and physiology of fish. The cultivation of $H$. intermedius is difficult due to this fish carnivorous habits, and photoperiod is closely related to this factor, acting directly or indirectly on fish behavior.

The objective of this work was to evaluate how different photoperiods affect the cannibalism, growth, and body composition of $H$. intermedius juveniles, since there is still little information available on these issues for this species.

\section{Materials and Methods}

The study was conducted at the photoperiod laboratory offish in the Biotério Central of Universidade Federal de Lavras, in the municipality of Lavras, in the state of Minas Gerais (MG), Brazil, from June 02 to October 28, 2012.

Juveniles of $H$. intermedius with $0.84 \pm 0.36 \mathrm{~g}$ and $3.5 \pm 0.2 \mathrm{~cm}$, at 30 days after hatching of the same spawning, were used. The animals were purchased from the fish farm station of Furnas Centrais Elétricas S.A., located in the municipality of São José da Barra, MG, Brazil. Fish were stocked at a density of 3 juveniles $\mathrm{L}^{-1}$ in glass tanks of $60 \mathrm{~L}$. The system had water recirculation with controlled temperature, using an electronic heater at $27^{\circ} \mathrm{C}$.

For the adaptation of the juveniles to commercial food, the animals were subjected to feed acclimation when they were still in Furnas, and the feed was made of zooplankton. This procedure took 24 days and followed the methodology adapted to that used by Salaro et al. (2011), by which the animals were fed with successive six diets for four days each. The diets were offered in the following order: $100 \%$ beef heart; $80 \%$ beef heart plus $20 \%$ commercial feed; $60 \%$ beef heart plus $40 \%$ commercial feed; $40 \%$ beef heart plus $60 \%$ commercial feed; $20 \%$ beef heart plus $80 \%$ commercial feed; and $100 \%$ commercial feed ( $45 \%$ crude protein). 
After feed acclimation, $176 \mathrm{H}$. intermedius juveniles were randomly selected. Fish had an initial mass of $5.23 \pm 1.61 \mathrm{~g}$ and a standard length of $6.70 \pm 0.72 \mathrm{~cm}$. The animals were divided into 11 fish per aquarium, in glass tanks of $60 \mathrm{~L}(60 \times 32 \times 31 \mathrm{~cm}$, length $\mathrm{x}$ width $\mathrm{x}$ height). All fish showed similar length and mass at the start of the trial.

The water system used an air compressor to recirculate with constant aeration, porous air stones, and temperature mantained at $27^{\circ} \mathrm{C}$. The water quality parameters were monitored daily for temperature, with a mercury thermometer, and $\mathrm{pH}$ with the Labcon Test pH Tropical (Alcon Pet, Camboriú, SC, Brazil). Oxygen, ammonia, and nitrite were measured weekly with the Labcon Test for Toxic Ammonia, dissolved $\mathrm{O}_{2}$ and nitrite $\mathrm{NO}_{2}{ }^{-}$(Alcon Pet, Camboriú, SC, Brazil). The values for $\mathrm{pH}$, ammonia, oxygen, and nitrite were $9.03 \pm 0.55,0.003 \pm 0.000 \mathrm{ppm}, 6.5 \pm 1.0 \mathrm{ppm}$ and $0.063 \pm 0.130 \mathrm{ppm}$, respectively.

A completely randomized design with four treatments and four replicates was used, and the tanks were considered the experimental units. The treatments consisted of the following photoperiods: 0L:24D, 6L:18D, 12L:12D and 18L:6D, in which L is light hours, and D is dark hours. Fish were maintained at their respective photoperiods for 10 days for acclimation to the new condition and, subsequently, the experiment started and had 90 days of duration.

Fluorescent lamps of $40 \mathrm{~W}$, with a light intensity of approximately $50.7 \mathrm{~lx}$, measured with a digital luximeter MLM-1010 (Minipa, São Paulo, SP, Brazil) at the surface of the aquaria, were used for lighting in each treatment. The lamps were controlled by timers with the light period beginning at 7:00 h, except for the lighting program in which fish were kept in 0L:24D scheme, and the lamp remained off for all the experimental period. For illumination of the experimental room, a red lamp of $40 \mathrm{~W}$ was used to do all the handling of animals, without any interference in the photoperiod. Treatments were isolated from each other by masonry walls, and at the front by a blackout system, preventing light interference between them.

The animals were fed twice a day, at 8:00 and 17:00 h, with the commercial extruded feed Fri-Aqua (Trouw Nutrition Brasil, Campinas, SP, Brazil) containing $45 \%$ crude protein in pellets of approximately $2 \mathrm{~mm}$ diameter, at a ratio of $3 \%$ of body mass per day. The remained pellets were taken $30 \mathrm{~min}$ after feeding the animals. Pellets were then frozen and dried at $65^{\circ} \mathrm{C}$ for further calculation of feed consumption and feed conversion.

The aquaria were monitored daily, in order to verify the presence of dead animals. Fish that were not found in the aquaria, and fish found dead with evidence of cannibalism (absence of a body part), were considered dead by cannibalism. Dead fish without signs of cannibalism were considered only for survival rate calculation. For the recalculation of the amount of daily feed (3\% of body mass), biometrics of all animals were performed at intervals of 15 days; the standard length was measured by an ictiometer, and the mass, with the aid of an analytical balance of $0.1 \mathrm{mg}$ accuracy. In order to avoid the stress of this procedure, the animals were anesthetized by immersion in water with benzocaine (190 $\mathrm{mg} \mathrm{L}^{-1}$ ) for approximately $2 \mathrm{~min}$.

At the end of 90 days, all fish were fasted for 24 hours, anesthetized by immersion in water with benzocaine (190 $\left.\mathrm{mg} \mathrm{L}^{-1}\right)$ for about $2 \mathrm{~min}$, weighed, and measured (standard length). Then, 23 fish from each replicate were euthanized by immersion in water with benzocaine $\left(250 \mathrm{mg} \mathrm{L}^{-1}\right)$; skeletal muscle tissue samples were removed, and the carcasses, without the viscera, were placed in identified plastic bags which were taken to the freezer and, subsequently, sent for the procedures of body composition analyses.

For the analyses of growth performance and survival, the variables were calculated as follows:

Survival rate, S (\%) = number of live/total fish) x 100;

Cannibalism rate, $\mathrm{C}(\%)=$ (number of dead fish by cannibalism/total fish) x 100;

Mass gain, $\mathrm{MG}(\mathrm{g})$ = final mass $(\mathrm{g})$ - initial mass (g);

Length gain, LG $(\mathrm{cm})=$ final length $(\mathrm{cm})-$ initial length $(\mathrm{cm})$;

Specific growth rate, SGR $\left(\%\right.$ day $\left.^{-1}\right)=[(\ln$ final mass - $\ln$ initial mass)/days] x 100;

Daily feed consumption, DFC $\left(\mathrm{g}\right.$ day $\left.^{-1}\right)=$ average total consumption of feed (g)/number of days;

Feed conversion, $\mathrm{FC}=$ average feed consumption (g)/ mass gain $(\mathrm{g})$; and

Protein efficiency rate, PER = mass gain $(\mathrm{g}) /$ protein intake (g).

In addition to these variables, the uniformity of mass and length of the tanks were calculated. To determine the uniformity of the aquarium, the following equation, proposed by Furuya et al. (1998), was used: $\mathrm{U}=\left[\left(\mathrm{N}_{ \pm 20 \%}\right) / \mathrm{N}_{\mathrm{t}}\right] \times 100$, in which $\mathrm{U}$ is the 
uniform experimental unit, which represents the variation of mass or length (\%); $\mathrm{N}_{\mathrm{t}}$ is the total number of fish in each experimental unit; and $\mathrm{N}_{ \pm 20 \%}$ is the number of animals that had $20 \%$ to more or less of the average mass and length for each experimental unit. This variables assess the uniformity on a scale of 0 to $100 \%$; values closer to $100 \%$ represent a greater degree of uniformity.

In the histology of muscle tissue, the individuals selected for muscle fiber analysis were randomly selected. Approximately $2 \mathrm{~cm}$ of muscle tissue samples were collected from the epiaxial portion, near to the dorsal fin, totalizing 11 animals per treatment. The samples were immersed in isopentane, frozen in liquid nitrogen $\left(-196^{\circ} \mathrm{C}\right)$, and stored in a freezer at $-80^{\circ} \mathrm{C}$. Later, cross sections of $10 \mu \mathrm{m}$ thickness in a cryostat at $-20^{\circ} \mathrm{C}$ were made and stained with hematoxylin-eosin.

Morphometric analyses of muscle fibers were performed. The smallest diameter of 200 white fibers of each animal was measured using a microscope connected to the computerized image analysis system AxioVision (Carl Zeiss Microscopy, Thornwood, NY, USA). Each muscle fiber was grouped into one of the three classes of diameter: $<20 \mu \mathrm{m}, 20-50 \mu \mathrm{m}$, and $>50 \mu \mathrm{m}$ (Almeida et al., 2008). The frequency of the muscle fibers was expressed as the number of fibers of each size class related to the total number of measured fibers.

In addition, the analysis of the body composition was performed. A total of 92 animals were used, and they were grouped according to the treatment and replicate to a specific pool. Each replicate was divided into two samples, which resulted in eight samples per treatment for the analyses of the body composition of the carcass: moisture; lipid (or ether extract); ash and crude protein, according to the AOAC International (Helrich, 1990).

The moisture content of fish carcasses was determined in kiln at $105^{\circ} \mathrm{C}$ for 24 hours until the obtention of constant mass. Lipids were determined by the Soxhlet method, by which $2 \mathrm{~g}$ of a sample were submerged in dry ethyl ether, leaving at reflux for 3 hours (Helrich, 1990). The samples were suspended to drain the excess solvent or oil for 30 min and, subsequently, with the recovery of the ether, only the lipids were left. The analysis of ash was done by the gravimetric method, based on the lost mass of the material subjected to heating at $550^{\circ} \mathrm{C}$ for 12 hours. For the crude protein content, measurements were performed by the micro Kjeldahl method (Helrich, 1990).
All animal experimental procedures in this study were approved by the animal ethics committee of Universidade Federal de Lavras (Standing Committees/ PRP-UFLA), and registered in the certificate number 004/14.

The variables were checked for normality by the Shapiro-Wilk's test and homoscedasticity of data variance by Levene's test. For the data considered as normally distributed, the one-way analysis of variance was applied, followed by the Tukey's test in case of significance, and for the data found to be not normally distributed, the Kruskal-Wallis' test was used. Additionally, a chi-square test was performed to check if the diameter of the fibers is dependent on the photoperiod. All analyses were performed with the program SPSS Statistics version 20, at 5\% probability.

\section{Results and Discussion}

Photoperiod affected survival and cannibalism $(p<0.05)$ of $H$. intermedius (Table 1). The 12L:12D photoperiod had the highest survival rate and no deaths by cannibalism. Additionally, the 12L:12D group showed high uniformity for length and mass of the animals. The opposite was observed for the 6L:18D treatment that showed the lowest survival rate and the highest cannibalism rate. The lowest uniformity was observed for both length and mass of $H$. intermedius in the 6L:18D group. Although the 0L:24D group showed higher uniformity values than the 12L:12D group, the first group had higher standard deviation than the second one, indicating a large variance.

The large size of heterogeneity is one of the causes of cannibalism, called cannibalism type II, in which the prey is completely consumed, generating significant high losses (Król \& Zieliński, 2015; Naumowicz et al., 2017). This was observed in the $6 \mathrm{~L}: 18 \mathrm{D}$ treatment that had the highest cannibalism rate. The long dark period (18 hours), followed by a short light period (6 hours), probably stimulated the dominance behavior of some animals, once the species becomes more active at night and prefer areas of low light conditions (Bussing, 2002). These dominant animals could feed more, increasing their size in relation to the other animals. The appearance of these size differences between animals resulted in cannibalism, which led to a decreased density of the aquaria, contributing to the growth of those dominant animals. A consequence of 
all these factors was an increase of the heterogeneity of the animals, which resulted in high cannibalism rates.

In the 12L:12D photoperiod, the great uniformity in the length and mass values of the animals causes the cannibalism decrease in this specie, thus favoring the survival (Luz et al., 2000). According to ReynalteTataje et al. (2002), there is a positive correlation between survival and the increase of the light period. In their study, Brycon orbignyanus larvae, a carnivorous fish at this stage of life, had the highest value of survival and uniformity among fish maintained under increasing periods of light ( 24 hours), and the lowest value of survival and heterogeneity of growth (because of cannibalism) when fish were subjected to a long dark period ( 0 hour). Our findings corroborate these data; however, for $H$. intermedius, it seems to exist a need for a long darkness period followed by short light stimulus to trigger cannibalism, since there was less survival and high cannibalism in the $6 \mathrm{~L}: 18 \mathrm{D}$, but not in the $0 \mathrm{~L}: 24 \mathrm{D}$ treatment.
Moreover, Salaro et al. (2011) found that $H$. intermedius juveniles, under different light intensities, including complete absence of light, have not been affected for their growth, survival, mortality, or cannibalism rates, during feed acclimation. Therefore, survival and cannibalism are possibly not affected by light intensity, but by photoperiod. However, Salaro et al. (2011) used a period of only 21 days in the experiment, which differ from this work, in which 90 days were used, representing another reason that may explain the differences in the survival and cannibalism rates.

Cannibalism and survival were also influenced by photoperiod in other species of carnivorous fish. $S$. scriptum larvae showed low survival to $0 \mathrm{~L}: 24 \mathrm{D}$ photoperiod due to high mortality and cannibalism (Schütz et al., 2008). According to these authors, the dark condition allows of the appearance of cannibalism and agonistic interactions. However, P. corruscans larvae showed high survival rate in the absence of light in the first five days, but later, under conditions of intermediate photoperiods (10L:14D, and 14L:10D),

Table 1. Mean \pm standard deviation of survival, uniformity, growth, and body composition parameters of Hoplias intermedius juveniles maintained in photoperiod treatments during 90 days $^{(1)}$.

\begin{tabular}{|c|c|c|c|c|c|}
\hline \multirow[t]{2}{*}{ Parameter } & \multicolumn{4}{|c|}{ Photoperiods (h; light:dark) } & \multirow[t]{2}{*}{ p-value } \\
\hline & 0L:24D & 6L:18D & 12L:12D & 18L:6D & \\
\hline \multicolumn{6}{|l|}{ Survival } \\
\hline Survival (\%) & $56.82 \pm 20.16 \mathrm{bc}$ & $34.09 \pm 11.44 \mathrm{c}$ & $97.73 \pm 4.55 \mathrm{a}$ & $63.64 \pm 12.86 \mathrm{~b}$ & 0.00 \\
\hline Cannibalism (\%) & $25.00 \pm 20.15 b$ & $59.09 \pm 11.73 \mathrm{a}$ & $0.00 \pm 0.00 \mathrm{c}$ & $25.00 \pm 17.20 \mathrm{~b}$ & 0.02 \\
\hline \multicolumn{6}{|l|}{ Uniformity $^{(2)}$} \\
\hline Length uniformity (\%) & $85.71 \pm 16.49$ & $57.50 \pm 43.49$ & $81.59 \pm 7.06$ & $75.80 \pm 9.89$ & - \\
\hline Mass uniformity (\%) & $31.99 \pm 12.43$ & $6.25 \pm 12.50$ & $30.23 \pm 8.57$ & $21.52 \pm 6.96$ & - \\
\hline \multicolumn{6}{|l|}{ Growth } \\
\hline Mass gain (g) & $10.51 \pm 5.10$ & $18.33 \pm 11.73$ & $6.23 \pm 1.85$ & $10.43 \pm 1.20$ & 0.07 \\
\hline Length gain $(\mathrm{cm})$ & $2.43 \pm 0.99$ & $5.84 \pm 1.82$ & $1.66 \pm 0.52$ & $2.71 \pm 0.18$ & 0.09 \\
\hline Specific growth rate (SGR, \% per day) & $1.21 \pm 0.31$ & $1.57 \pm 0.59$ & $0.84 \pm 0.16$ & $1.20 \pm 0.07$ & 0.06 \\
\hline Daily feed consumption (DFC, g per day) & $0.19 \pm 0.09$ & $0.27 \pm 0.11$ & $0.10 \pm 0.02$ & $0.15 \pm 0.03$ & 0.05 \\
\hline Feed conversion $(\mathrm{FC})$ & $1.51 \pm 0.03$ & $1.50 \pm 0.61$ & $1.43 \pm 0.17$ & $1.22 \pm 0.12$ & 0.31 \\
\hline Protein efficiency rate (PER) & $1.47 \pm 0.03$ & $1.71 \pm 0.76$ & $1.57 \pm 0.19$ & $1.83 \pm 0.19$ & 0.64 \\
\hline \multicolumn{6}{|l|}{ Body composition } \\
\hline Moisture (\%) & $72.51 \pm 0.22$ & 72.950 .75 & 72.310 .48 & 72.380 .27 & 0.05 \\
\hline Lipid (\%) & $4.130 .10 \mathrm{ab}$ & $3.760 .26 \mathrm{c}$ & $4.230 .26 \mathrm{a}$ & $3.870 .34 \mathrm{bc}$ & 0.00 \\
\hline Ash (\%) & 3.920 .13 & 3.960 .23 & 3.950 .25 & 4.020 .29 & 0.85 \\
\hline Crude protein $(\mathrm{CP}, \%)$ & 17.140 .26 & 16.980 .77 & 16.900 .59 & 16.271 .25 & 0.17 \\
\hline
\end{tabular}


fish showed the best survival rates (Campagnolo \& Nuñer, 2008). Therefore, differences for survival of different species can be attributed to variations in the photoperiod requirement, which is species specific and depends on the development stage of the animal.

The manipulation did not show influence on mass gain, length gain, specific growth rate, daily feed consumption, feed conversion and protein efficiency rate $(\mathrm{p}>0.05$, Table 1). The same fact occurred in Lophiosilurus alexandri, that also showed no difference for growth when fish were maintained in different photoperiods (Kitagawa et al., 2015). The length and mass of $B$. orbignyanus postlarvae did not show significant differences between treatments (14L:10D, 10L:14D, 24L:0D, and 0L:24D), but a great heterogeneity was observed between postlarvae cultivated in the condition of long darkness period (Reynalte-Tataje et al., 2002).

In the histology of muscle tissue, the average diameter of white muscle fibers showed a significant difference among photoperiod treatments $(\mathrm{p}<0.05)$. The animals from the $6 \mathrm{~L}: 18 \mathrm{D}$ and $18 \mathrm{~L}: 6 \mathrm{D}$ groups had the highest fiber diameter (56.36 \pm 25.85 and $56.08 \pm 28.91 \mu \mathrm{m}$, mean \pm standard error, respectively), with no statistic difference between them. However, the 0L:24D and 12L:12D groups showed the lowest diameter values with $50.91 \pm 24.76$ and $50.65 \pm 24.33 \mu \mathrm{m}$, mean \pm standard error, respectively, with no difference between them.

For each photoperiod, a low number of white muscle fibers $(<20 \mu \mathrm{m}$ diameter) and a large number of fibers with a diameter $>50 \mu \mathrm{m}$ were observed for all treatments, which indicated that the growth in this species occurs by hypertrophy (Figure 1). However, fish from the 6L:18D and 18L:6D photoperiods had greater degrees of distribution than those of the $0 \mathrm{~L}: 24 \mathrm{D}$ and 12L:12D $(\mathrm{p}<0.05)$ groups. The 6L:18D group showed $56.73 \%$ of the total fiber measures, and belongs to the class $>50 \mu \mathrm{m}$, and the 18L:6D group showed $55.73 \%$ of the fibers in the same class. The 0L:24D and 12L:12D photoperiods had lower frequencies of fibers $>50 \mu \mathrm{m}$, which were $50.13 \%$ and $47.32 \%$, respectively.

The 6L:18D and 18L:6D groups were those with the largest diameters of muscle fibers and the highest frequencies in the number of fibers in class $>50 \mu \mathrm{m}$, indicating that these photoperiods may have caused a great hypertrophy in the muscle tissue (Almeida et al., 2008). In other species, the continuous light resulted in high hypertrophic growth of muscle tissue in Hippoglossus hippoglossus, with the largest diameter of $50.71 \pm 1.24 \mu \mathrm{m}$, mean \pm standard deviation (Lohne et al., 2012), and Umbrina cirrosa showed a great hypertrophy of white fibers in the 16L:8D photoperiod (Ayala et al., 2013). This may be due to the increased activity of animals during long photoperiods, which probably resulted in the high hypertrophy of white fibers, as occurred in the 18L:6D group in the present work.

A high cannibalism rate was observed in the $6 \mathrm{~L}: 18 \mathrm{D}$ group, which may have led to great hypertrophy of fish white fibers. This increase may be due to three factors: first, to the food type consumed, since digestible nutrients are often higher in fish that increase growth (Król \& Zieliński, 2015); second, to the decreasing fish density in the aquaria, which also promotes the growth (Lima \& Barbosa, 2016); and third, to the high fish activity due to chases and fights of cannibalism. This can also be observed by the low uniformity found in this group, both in fish mass and length. Therefore,

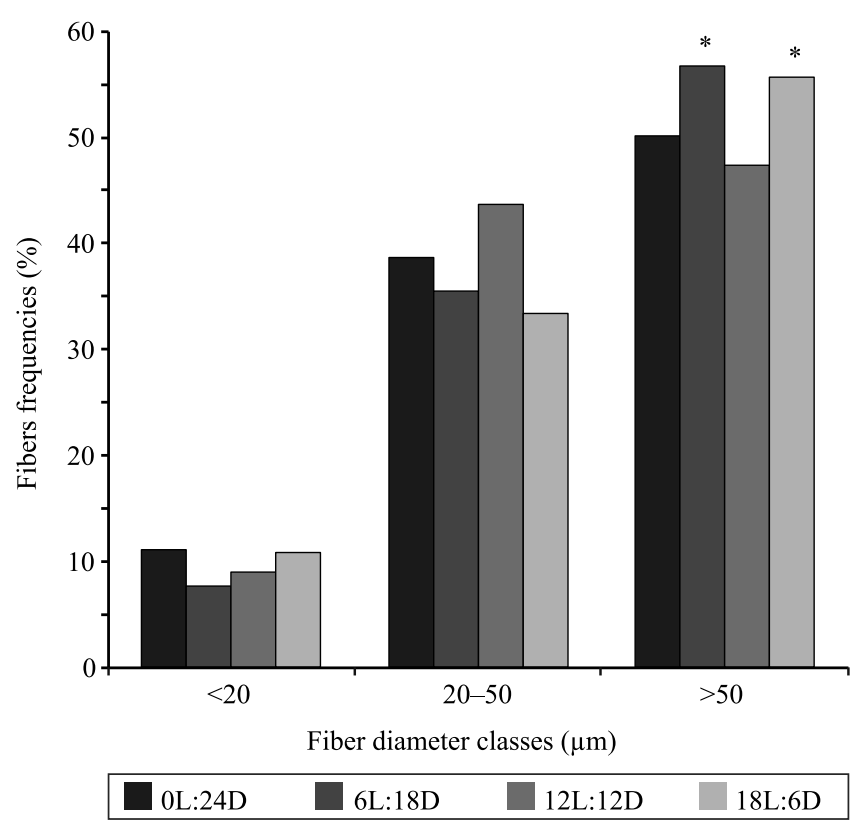

Figure 1. White muscle fiber diameter distribution in Hoplias intermedius juveniles subjected to photoperiod treatments during 90 days. Columns represent white fibers frequencies in each fiber diameter class. L:D, light:dark hours; *Significant difference at 5\% probability from each other within the class $>50 \mu \mathrm{m}$ by the chi-square test. 
it is possible that the largest animals have contributed to the increase of average diameter and frequency of large diameter fibers because of the increased length and mass (Nejedli et al., 2011).

The analysis of body composition showed no significant difference among photoperiods $(p>0.05$, Table 1), for the average values of moisture, ash, and crude protein, in the carcass of $H$. intermedius juveniles. However, there was an effect of photoperiod on the lipid contents $(\mathrm{p}<0.05)$, in which the animals from the 12L:12D photoperiod had higher lipid levels than the $6 \mathrm{~L}: 18 \mathrm{D}$ and $18 \mathrm{~L}: 6 \mathrm{D}$ groups, but similar values to those of the 0L:24D group.

This work found similar values to those found by Santos et al. (2000/2001) in fillet trahira Hoplias malabaricus. In H. malabaricus, $77.71 \%$ moisture, $20.7 \%$ crude protein, $1.39 \%$ ash, and $0.84 \%$ lipid were observed. In $O$. niloticus, the percentage of moisture and ash did not change with different photoperiods, which was also observed for $H$. intermedius in the present work (Veras et al., 2014). However, also crude protein did not change in $H$. intermedius because of photoperiod, which is opposite what is observed in the above mentioned species.

Only lipid was influenced by photoperiod, since the animals from the $6 \mathrm{~L}: 18 \mathrm{D}$ group showed the lowest value for this parameter. Possibly, fish subjected to this photoperiod showed an increased mobilization of lipids required to cover high energy demand due to high activity such as fights and escape from cannibalism, as lipids are catabolized to meet the energy demands of muscles (Fabrizzi et al., 2013). Furthermore, with cannibalism, this fish species eats a more complete food, and easy digestion and absorption occur, which reduces the deposition of lipids (Kolkovski, 2001). Nevertheless, the animals from the 12L:12D photoperiod had a high lipid value, indicating a low energy demand due to low activity of the animals (no cannibalism). Besides, this fish species ate only a commercial feed that has a significant amount of carbohydrates which was directed towards the fat deposition (Silveira et al., 2009), and it has lower digestible nutrients than a fish ingested by cannibalism (Król \& Zieliński, 2015).

The lipid content is used as a criterion for comparing different species of fish, by which fish are considered fat with a minimal of $10 \%$ lipid content, semi-thin from 2.5 to $10 \%$ lipid content, and thin with a maximum of $2.5 \%$ lipid content (Veras et al., 2014). Thereby, the lipid contents observed in the present study allow us to consider $H$. intermedius juveniles as a semi-thin product. This knowledge is of importance for the validity of commercial fish and it is essential for the consumer acceptance.

\section{Conclusions}

1. The photoperiod treatments affect survival and cannibalism, and the best photoperiod for Hoplias intermedius juveniles is 12L:12D (light:dark) hours, since fish in this treatment show growth uniformity (length and mass values) and no cannibalism, while fish from the 6L:18D and 18L:6D groups have a greater diameter of white muscle fibers, and higher frequency of greater diameter fibers.

2. As to body composition, only lipids are influenced by photoperiods; giant trahira juveniles show the lowest values in the $6 \mathrm{~L}: 18 \mathrm{D}$ treatment, and the highest values in the $12 \mathrm{~L}: 12 \mathrm{D}$ treatment.

\section{Acknowledgments}

To Coordenação de Aperfeiçoamento de Pessoal de Nível Superior (Capes), Conselho Nacional de Desenvolvimento Científico e Tecnológico (CNPq), and Fundação de Amparo à Pesquisa do Estado de Minas Gerais (Fapemig), for financial support; to the hydrobiology and fish farm station of Furnas, for fish supply; and to the laboratory of chemistry, biochemistry and food analyses of Departamento de Ciências dos Alimentos of Universidade Federal de Lavras, for data analyses.

\section{References}

ALMEIDA, F.L.A. de; CARVALHO, R.F.; PINHAL, D.; PADOVANI, C.R.; MARTINS, C.; DAL PAI-SILVA, M. Differential expression of myogenic regulatory factor MyoD in pacu skeletal muscle (Piaractus mesopotamicus Holmberg 1887: Serrasalminae, Characidae, Teleostei) during juvenile and adult growth phases. Micron, v.39, p.1306-1311, 2008. DOI: 10.1016/j. micron.2008.02.011.

AYALA, M.D.; ABELLÁN, E.; ARIZCUN, M.; GARCÍAALCÁZAR, A.; NAVARRO, F.; BLANCO, A.; LÓPEZ-ALBORS, O.M. Muscle development and body growth in larvae and early post-larvae of shi drum, Umbrina cirrosa L., reared under different larval photoperiod: muscle structural and ultrastructural study. Fish Physiology Biochemistry, v.39, p.807-827, 2013. DOI: $10.1007 / \mathrm{s} 10695-012-9742-x$. 
BISWAS, A.K.; SEOKA, M.; INAGAKI, H.; TAKII, K. Reproduction, growth and stress response in adult red sea bream, Pagrus major (Temminck \& Schlegel) exposed to different photoperiods at spawning season. Aquaculture Research, v.41, n.4, p.519-527, 2010. DOI: 10.1111/j.1365-2109.2009.02341.x.

BISWAS, A.K.; SEOKA, M.; UENO, K.; TAKII, K.; KUMAI, H. Stimulation of growth performance without causing stress response in young red sea bream, Pagrus major (Temminck \& Schlegel), by photoperiod manipulation. Aquaculture Research, v.39, p.457-463, 2008. DOI: 10.1111/j.1365-2109.2008.01897.x.

BUSSING, W.A. Peces de las aguas continentales de Costa Rica - Freshwater fishes of Costa Rica. 2.ed. San Jose: Universidad de Costa Rica, 2002. 468p.

CAMPAGNOLO, R.; NUÑER, A.P.O. Survival and growth of Pseudoplatystoma corruscans (Pisces - Pimelodidae) larvae: effect of photoperiod. Arquivo Brasileiro de Medicina Veterinária e Zootecnia, v.60, p.1511-1516, 2008. DOI: 10.1590/ S0102-09352008000600030.

FABRIZZI, F.; MORAES, G.; HACKBARTH, A.; ALMEIDA, L.C. de; ARBELÁEZ-ROJAS, G.; NUNES, C. da S. Intermittent sustained swimming in 'matrinxã' Brycon amazonicus (Bryconidae: Bryconinae): hematological and metabolic responses. Neotropical Ichthyology, v.11, p.425-432, 2013. DOI: 10.1590/S1679-62252013000200013.

FALCÓN, J.; MIGAUD, H.; MUÑOZ-CUETO, J.A.; CARRILLO, M. Current knowledge on the melatonin system in teleost fish. General and Comparative Endocrinology, v.165, p.469-482, 2010. DOI: 10.1016/j.ygcen.2009.04.026.

FURUYA, W.M.; SOUZA, S.R. de; FURUYA, V.R.B.; HAYASHI, C.; RIBEIRO, R.P. Dietas peletizada e extrusada para machos revertidos de tilápia do Nilo (Oreochromis niloticus L.) na fase de terminação. Ciência Rural, v.28, p.483-487, 1998. DOI: 10.1590/ S0103-84781998000300022.

HELRICH, K. (Ed.). International. Association of Official Analytical Chemists International. Official methods of analysis of the Association of Official Analytical Chemists. 15th ed. Arlington: Association of Official Analytical Chemists, 1990. v.1, 684p.

JOHNSTON, I.A. Environment and plasticity of myogenesis in teleost fish. Journal of Experimental Biology, v.209, p.22492264, 2006. DOI: 10.1242/jeb.02153.

JOHNSTON, I.A.; LEE, H.-T.; MACQUEEN, D.J.; PARANTHAMAN, K., KAWASHIMA, C.; ANWAR, A.; KINGHORN, J.R.; DALMAY, T. Embryonic temperature affects muscle fibre recruitment in adult zebrafish: genome-wide changes in gene and microRNA expression associated with the transition from hyperplastic to hypertrophic growth phenotypes. Journal of Experimental Biology, v.212, p.1781-1793, 2009. DOI: 10.1242/ jeb.029918.

KITAGAWA, A.T.; COSTA, L.S.; PAULINO, R.R.; LUZ, R.K.; ROSA, P.V.; GUERRA-SANTOS, B.; FORTES-SILVA, R. Feeding behavior and the effect of photoperiod on the performance and hematological parameters of the pacamã catfish (Lophiosilurus alexandri). Applied Animal Behaviour Science, v.171, p.211-218, 2015. DOI: 10.1016/j.applanim.2015.08.025.
KOLKOVSKI, K. Digestive enzymes in fish larvae and juveniles - implications and applications to formulated diets. Aquaculture, v.200, p.181-201, 2001. DOI: 10.1016/S0044-8486(01)00700-1.

KRÓL, J.; ZIELIŃSKI, E. Effects of stocking density and weaning age on cannibalism, survival and growth in European perch Perca fluviatilis larvae. Polish Journal of Natural Sciences, v.30, p.403-415, 2015.

LIMA, A.F.; BARBOSA, J.M. Crescimento, sobrevivência e resistência de larvas de tilápia em função da densidade e da suplementação com vitamina C. Archivos de Zootecnia, v.65, p.117-121, 2016.

LOHNE, P.; IMSLAND, A.K.; LARSEN, S.; FOSS, A.; PITTMAN, K. Interactive effect of photoperiod and temperature on the growth rates, muscle growth and feed intake in juvenile Atlantic halibut. Aquaculture Research, v.43, p.187-197, 2012. DOI: 10.1111/j.1365-2109.2011.02815.x.

LUZ, R.K.; SALARO, A.N.; SOUTO, E.F.; ZANIBONI FILHO, E. Avaliação de canibalismo e comportamento territorial de alevinos de trairão (Hoplias lacerdae). Acta Scientiarum. Biological Sciences, v.22, p.465-469, 2000. DOI: 10.4025/ actascibiolsci.v22i0.2929.

NAUMOWICZ, K.; PAJDAK, J.; TERECH-MAJEWSKA, E.; SZAREK, J. Intracohort cannibalism and methods for its mitigation in cultured freshwater fish. Reviews in Fish Biology and Fisheries, v.27, p.193-208, 2017. DOI: 10.1007/s11160-0179465-2.

NEJEDLI, S.; KAZARIC, Z.; TLAK GAJGER, I.; MATASIN, Z. Relationsheep beetwen length, body weight, and histomorphology trank muscles of Common Pandora (Pagellus erythrinus Lineatus, 1758). Journal of Animal and Veterinary Advances, v.10, p.2181-2185, 2011. DOI: 10.3923/javaa.2011.2181.2185.

REYNALTE-TATAJE, D.; LUZ, R.K.; MEURER, S.;ZANIBONIFILHO, E.; NUÑER, A.P. de O. Influência do fotoperíodo no crescimento e sobrevivência de pós larvas de piracanjuba Brycon orbignyanus (Valenciennes, 1849) (Osteichthyes, Characidae). Acta Scientiarum. Biological Sciences, v.24, p.439-443, 2002. DOI: $10.4025 /$ actascibiolsci.v24i0.2317.

SALARO, A.L.; TAVARES, M.M.; CHAVES, W.; CAMPELO, D.A.V.; ZUANON, J.A.S.; LUZ, R.K. Feed training of juvenile giant trahira under different light intensities. Revista Brasileira de Zootecnia, v.40, p.2290-2293, 2011. DOI: 10.1590/S151635982011001100002 .

SANTOS, A.B.; MELO, J.F.B.; LOPES, P.R.S.; MALGARIM, M.B. Composição química e rendimento do filé da traíra (Hoplias malabaricus). Revista da FZVA, v.7/8, p.140-150, 2000/2001.

SCHÜTZ, J.H.; WEINGARTNER, M.; ZANIBONI-FILHO, E.; NUÑER, A.P. de O. Crescimento e sobrevivência de larvas de suruvi Steindachneridion scriptum nos primeiros dias de vida: influência de diferentes alimentos e fotoperíodos. Boletim do Instituto de Pesca, v.34, p.443-451, 2008.

SILVEIRA, U.S. da; LOGATO, P.V.R.; PONTES, E. da C. Utilização e metabolismo dos carboidratos em peixes. Revista Eletrônica Nutritime, v.6, p.817-836, 2009. 
TAYLOR, J.; MIGAUD, H. Timing and duration of constant light affects rainbow trout (Oncorhynchus mykiss) growth during autumn-spring grow-out in freshwater. Aquaculture Research, v.40, n.13, p.1551-1558, 2009. DOI: 10.1111/j.13652109.2009.02260.x.
VERAS, G.C.; MURGAS, L.D.S.; ZANGERONIMO, M.G.; ROSA, P.V.; MIRANDA, J.R.; BRABO, M.F. Efeito do fotoperíodo sobre a composição do filé de juvenis de tilápia do Nilo. Ciência Animal Brasileira, v.15, p.168-173, 2014. DOI: 10.1590/18096891v15i22238.

Received on April 24, 2017 and accepted on September 21, 2017 